\title{
Evaluation of the melting capacity of Prato cheese obtained by modifications of the traditional manufacturing process
}

\author{
Leila Maria SPADOTI ${ }^{\mathrm{a}}$, José Raimundo Ferreira DORNELlas ${ }^{\mathrm{a}}$, \\ José Ademir PETENATE ${ }^{\mathrm{b}}$, Salvador Massaguer ROIG ${ }^{\mathrm{a} *}$ \\ a Departamento de Tecnologia de Alimentos, Faculdade de Engenharia de Alimentos, \\ Universidade Estadual de Campinas-UNICAMP, \\ Caixa Postal 6121, CEP: 13083-970, Campinas, SP, Brazil \\ b Instituto de Matemática e Estatística, Universidade Estadual de Campinas-UNICAMP, \\ CEP: 13083-970, Campinas, SP, Brazil
}

Received 11 December 2002 - Accepted 29 April 2003

Published online 22 September 2003

\begin{abstract}
The objective of this research was to study the effect of the following modifications to the traditional manufacturing process of Prato cheese: use of milk concentrated by ultrafiltration (UFCM) up to a concentration factor (CF) of 4:1, and partial pre-fermentation of the UFCM and indirect curd cooking on the composition, $\mathrm{pH}$, titratable acidity (TA) and melting capacity (MC) of the cheese as compared with the standard cheese. Three processings of each of the following five treatments were carried out: Treatment 1 (T1), without ultrafiltration; Treatment 2 (T2), ultrafiltration without pre-fermentation of the UFCM; Treatment 3 (T3), pre-fermentation of $100 \mathrm{~g} \cdot \mathrm{kg}^{-1}$ of the UFCM; Treatment 4 (T4), pre-fermentation of $200 \mathrm{~g} \cdot \mathrm{kg}^{-1}$ of the UFCM; and Treatment 5 (T5), pre-fermentation of $200 \mathrm{~g} \cdot \mathrm{kg}^{-1}$ of the UFCM, and the only one with indirect curd heating. There was a significant difference for total solids between cheeses T4 and T5 with respect to T2. T2 presented the lowest fat and fat in dry matter content, although the observed differences were not statistically significant. The UFCM cheeses presented lower values for fat recovery in cheeses with a significant difference between the treatments $\mathrm{T} 2$ and $\mathrm{T} 3$ with respect to $\mathrm{T} 1$, the fat losses in processing being the main factor affecting cheeses' composition. The pre-fermentation of $200 \mathrm{~g} \cdot \mathrm{kg}^{-1}$ of the UFCM increased the acidity and reduced the $\mathrm{pH}$ of the cheeses. The time did not exert an influence on the $\mathrm{pH}$ but it increased cheeses's TA and MC. There was no difference in MC between the treatments but there was a tendency for greater $\mathrm{MC}$ values for cheeses with a higher water to total protein ratio and higher $\mathrm{pH}$ value.
\end{abstract}

Cheese / ultrafiltration / pre-fermentation / cooking / melting

Résumé - Évaluation de la capacité de fusion du fromage «Prato » obtenu par modifications du procédé de fabrication traditionnel. L'objectif de cette recherche était d'étudier l'effet de modifications du procédé de fabrication traditionnel du fromage «Prato » sur la composition, le $\mathrm{pH}$, l'acidité titrable (TA) et la capacité de fusion (MC) du fromage, comparé au standard traditionnel. Les modifications ont été les suivantes : utilisation de lait concentré par ultrafiltration (UFCM) jusqu'à un facteur de concentration (CF) de 4:1 ; pré-fermentation partielle de l'UFCM et

\footnotetext{
*Corresponding author: salvador@fea.unicamp.br
} 
cuisson indirecte du caillé. Trois répétitions ont été réalisées pour chacun des cinq traitements suivants : traitement 1 (T1), sans ultrafiltration; traitement 2 (T2), ultrafiltration sans préfermentation de l'UFCM ; traitement 3 (T3), pré-fermentation de $100 \mathrm{~g} \cdot \mathrm{kg}^{-1}$ de l'UFCM, traitement (T4), pré-fermentation de $200 \mathrm{~g} \cdot \mathrm{kg}^{-1}$ de l'UFCM ; traitement 5 (T5), pré-fermentation de $200 \mathrm{~g} \cdot \mathrm{kg}^{-1}$ de l'UFCM. Une cuisson indirecte du caillé a été utilisée seulement dans le cas du traitement 5. L'analyse des données statistiques a montré que les fromages T4 et T5 ont présenté une différence significative par rapport au fromage $\mathrm{T} 2$. Ce fromage a présenté les plus faibles teneurs en matière grasse et en matière grasse dans la matière sèche, bien que les différences observées ne soient pas statistiquement significatives. Les fromages UFCM ont présenté une valeur plus faible pour la récupération de matière grasse dans les fromages avec une différence significative pour les traitements T2 et T3 par rapport à T1, la perte de matière grasse dans le processus étant le principal facteur affectant la composition des fromages. La pré-fermentation de $200 \mathrm{~g} \cdot \mathrm{kg}^{-1}$ du rétentat a augmenté l'acidité et réduit le $\mathrm{pH}$; le temps n'a pas eu d'influence sur le $\mathrm{pH}$, mais la TA et la MC ont eu tendance à augmenter. Il n'y a pas eu de différence de MC entre les traitements mais les MC des fromages ayant un ratio eau/protéines totales et un $\mathrm{pH}$ plus élevés, ont eu tendance à augmenter.

Fromage / ultrafiltration / pré-fermentation / cuisson / fusion

\section{INTRODUCTION}

Prato cheese is one of the most produced cheeses in Brazil [34], being considered a cheese from semi-cooked and washed curd where the heating of the curd grains is obtained by the addition of hot water to the whey $[1,11,38,45,47]$, this operation being indispensable to obtaining the organoleptic properties of the final product $[45,47]$. However, the washing of the curd results in considerable losses of soluble constituents, which are removed together with the whey [12], tending to decrease the yield.

This cheese is popularly used as an ingredient in various dishes in which the cheese is frequently melted [27]. The use of Mozzarella, Cheddar and Prato cheeses in pizzas, toasted sandwiches and frozen foods are examples of this. For these cheeses, good melting properties are one of the determinant factors in their quality evaluation [28].

Thus numerous research results have been reported about the influence of the production variables (starters, coagulant kind and concentration, whey draining $\mathrm{pH}$, and heat treatment during curd cooking), composition (moisture, salt, fat and calcium content), proteolysis and microstruc- ture of the cheeses on their MC [5, 18-20, $22,27,28,33,35,43]$. With respect to composition, cheeses with higher water and fat content present the tendency to larger MC [19, 20, 28, 33, 43] and cheeses with a higher salt and mineralization degree (calcium content) have the tendency to lower MC [19, 20].

In Brazil, Prato cheese, like the majority of the other cheeses produced there, is obtained from non-concentrated milk. However, in countries such as Australia, France, the USA and others, there are frequent reports of cheese manufacture from milk concentrated by the technique of ultrafiltration [8, 15-17, 26, 29, 31].

The use of this technique, known as MMV, was proposed by Maubois et al. [32], based on the concentration of milk by ultrafiltration (UF) until a liquid pre-cheese was obtained, with a total solids content similar to that found in a finished cheese. The process shows the advantages of eliminating the draining stage, allowing a greater retention of milk fat and whey proteins, principally $\alpha$-lactalbumin and $\beta$-lactoglobulin, which are normally lost during this stage in the traditional cheese processing. Thus, in addition to producing a permeate with a smaller biological oxygen demand, the MMV method also results in an increase 
in the yield of cheese, from 8 to $20 \%$ [17, 24, 26, 30, 32, 36].

Despite the advantages offered by the MMV method, it is difficult to concentrate up to the levels required for hard and semihard cheeses using UF [17], and when one does manage to reach these levels, the cheeses obtained tend to show inferior quality as compared with cheeses produced by the traditional process $[13,29]$. According to Renner and Abd El-Salam [40], semi-hard cheeses obtained by UF either do not melt or melt to a lesser extent when compared with cheeses produced by the traditional method.

As a result of the above-mentioned motives, some researchers [16, 17], tested the production of semi-hard and hard cheeses from milks concentrated to intermediate CF (p/p) values (4:1 to $6: 1)$, and subsequently following the traditional processing steps. Although it did not result in great gains in yield, the use of intermediate $\mathrm{CF}$ allowed an increase in yield as compared with that of the traditional process $[16,17]$. In addition, it resulted in a reduction in milk transportation costs, decrease in water consumption, increase in plant productivity and the production of cheeses with functional and organoleptic characteristics closer to those of the traditional cheeses [15, 40, 50].

In Australia, in the manufacture of Cheddar cheese from milk partially concentrated by UF, pre-fermentation of part of the retentate has been used, normally about $100 \mathrm{~g} \cdot \mathrm{kg}^{-1}$, in order to obtain curd of normal strength, since the fermentation results in a significant production of ionized calcium, which helps in the formation of a coagulum [16]. Such a technique is necessary since the production of cheeses by ultrafiltration is slightly quicker than the traditional process and the use of this technique provides an adequate number of lactic bacteria in the final product [16].

Ribeiro [41] produced Prato cheese from UFCM with various CF $(1.5: 1 ; 2.5: 1$; 3.5:1 and 5.0:1), and concluded that the use of such retentates allowed one to obtain cheeses with typical organoleptic and textural characteristics and a greater yield than the traditional process. In the case of the cheese produced from a retentate with a $\mathrm{CF}$ of $5: 1$, it was only possible to obtain an adequate texture by pre-fermenting part $\left(100 \mathrm{~g} \cdot \mathrm{kg}^{-1}\right)$ of the retentate with a lactic culture. However, this author did not study the effect of the use of UFCM and partiallyfermented UFCM on the melting capacity of Prato cheese.

The objective of this research was to study the effect of the following modifications to the traditional manufacturing process of Prato cheese: use of milk concentrated by ultrafiltration up to a $\mathrm{CF}$ value $=$ $4: 1$, and partial (100 and $200 \mathrm{~g} \cdot \mathrm{kg}^{-1}$ ) prefermentation of the UFCM and indirect curd cooking on the composition, $\mathrm{pH}$, TA and $\mathrm{MC}$ of the resulting cheeses as compared with the standard cheese.

\section{MATERIALS AND METHODS}

\subsection{Ultrafiltration of the milk}

Type B raw milk $(250 \mathrm{~kg}$ ) from the Milk Producers' Cooperative in the Campinas Region was heat treated at $68^{\circ} \mathrm{C} / 2 \mathrm{~min}$. One part of this milk $(50 \mathrm{~kg})$ was cooled to $35^{\circ} \mathrm{C}$ and used to produce a batch of standard Prato cheese (T1) and the other part (200 kg) was cooled to $55^{\circ} \mathrm{C}$ and submitted to concentration by ultrafiltration. The milk was concentrated with Carbosep mineral membranes (Tech-Sep - Groupe Rhône Poulenc, SaintMaurice de Beynost, France) with a molecular mass cut-off of $20000 \mathrm{~g} \cdot \mathrm{mol}^{-1}$ and inlet and outlet pressures of $2.45 \times 10^{5}$ and $1.47 \times 10^{5} \mathrm{~Pa}$, respectively, up to a CF of $4: 1$. The ultrafiltration concentration process was performed in approximately $10 \mathrm{~h}$, after which the ultrafiltered milk was pasteurized at $62^{\circ} \mathrm{C}$ for $30 \mathrm{~min}$, cooled to $7^{\circ} \mathrm{C}$ and divided into four equal parts (T2, T3, T4 and T5). 


\subsection{Cheese manufacture}

Three processing procedures were carried out in this experiment, on different dates. In each processing, five batches of Prato cheese were manufactured (T1, T2, T3, T4 and T5). Batch T1 was processed by the conventional method from non-concentrated milk on the same day the milk was delivered to the pilot plant. The other four batches were manufactured the next day from UFCM. In the case of the cheeses manufactured from UFCM (T2, T3, T4 and T5), after cooling each of the four parts, a certain portion was removed from each $\left(0 \mathrm{~g} \cdot \mathrm{kg}^{-1}\right.$ from T2; $100 \mathrm{~g} \cdot \mathrm{kg}^{-1}$ from T3 and $200 \mathrm{~g} \cdot \mathrm{kg}^{-1}$ from T4 and T5) and submitted to a pre-fermentation with a mesophilic starter (G3 MIX 6-VISBYVA ${ }^{\circledR}$-B50, composed of multiple mixed strains of Lactococcus lactis ssp. lactis and Lactococcus lactis ssp. cremoris) at $32{ }^{\circ} \mathrm{C}$. The rest of the UFCM was stored at $5 \pm 1{ }^{\circ} \mathrm{C}$ until the next day. After the separated portions had reached $\mathrm{pH} 5.0$, they were mixed with their respective UFCM batches, then the retentate was heated to $35^{\circ} \mathrm{C}$ to start the processing of the cheese. Both the standard cheese and those prepared from UFCM were manufactured according to the basic steps of the traditional processing of Prato cheese. For the standard cheese, 50\% calcium chloride $\left(0.4 \mathrm{~mL} \cdot \mathrm{kg}^{-1}\right.$ milk $)$ was added to the milk already heated to $35^{\circ} \mathrm{C}$, followed by the addition of freeze-dried ready-to-use starter (one-tenth of the quantity recommended by the manufacturer), annatto dye (Bixa orellana) (Chr. Hansen Ind. E Com. Ltda, Valinhos, SP, Brazil) and rennet (calf rennet - 90\% chymosin) (BV Ind. E Com. Ltda, Valinhos, SP, Brazil) in a quantity sufficient to coagulate the milk at $35{ }^{\circ} \mathrm{C}$. A similar procedure was used for the cheeses manufactured from UFCM, using starter, dye and coagulating agent in quantities equivalent to what would be used if one converted the UFCM into milk, but without the addition of calcium chloride. After coagulation (40 min for all treatments), the curd was cut into
$0.4 \mathrm{~cm} \times 0.5 \mathrm{~cm}$ cubes, and allowed to rest for $5 \mathrm{~min}$. The curds were then submitted to slow continuous mixing for $20 \mathrm{~min}(1 \mathrm{st}$ mixing), followed by removal of part of the whey and further heating of the curd (2nd mixing) to $41{ }^{\circ} \mathrm{C}$ with the addition of hot water, in order to obtain the correct consistency for Prato cheese. For the cheeses obtained from UFCM, no 1st mixing or removal of the whey was carried out, the curd being heated soon after the resting period, resulting in a reduction of the processing time of about $30 \mathrm{~min}$. For the cheeses T2, T3 and T4, the curd was heated directly by the addition of hot water. For $\mathrm{T} 5$, the curd was heated indirectly. After heating, the curds were pre-pressed for 20 min in a draining press with twice the weight of the curd, and then placed in plastic molds and pressed for $6 \mathrm{~h}$ in a vertical press, with stainless steel weights. The cheeses were turned after 20 min during pressing and then every hour until removed from the press. The weights were gradually increased from 10 to 20 times the weight of the curd. Having completed the pressing time, the cheeses were stored at $7 \pm 1{ }^{\circ} \mathrm{C}$ and the next day placed in a $200 \mathrm{~g} \cdot \mathrm{kg}^{-1}$ $(\mathrm{NaCl})$ brine solution for a period of $8 \mathrm{~h}$ at $4 \pm 1^{\circ} \mathrm{C}$. Finally, they were dried at $7 \pm 1^{\circ} \mathrm{C}$, weighed, sealed under vacuum in heat-shrinkable plastic bags and stored at $7 \pm 1{ }^{\circ} \mathrm{C}$ for $45 \mathrm{~d}$.

\subsection{Analyses}

\subsubsection{Composition of the cheeses}

Total nitrogen (TN) was determined using the Kjeldahl method according to AOAC method 991.20 [2], using a factor of 6.38 to determine total protein. Soluble nitrogen at $\mathrm{pH} 4.6$ (non-casein nitrogen NCN) was determined according to Barbano et al. [3]. Total solids (TS) content was determined using AOAC method 925.23 [2], and the moisture (M) content using the equation: $M=1000-T S$. The fat content was determined by the Gerber method [7] and the fat content in the dry matter (FDM) 


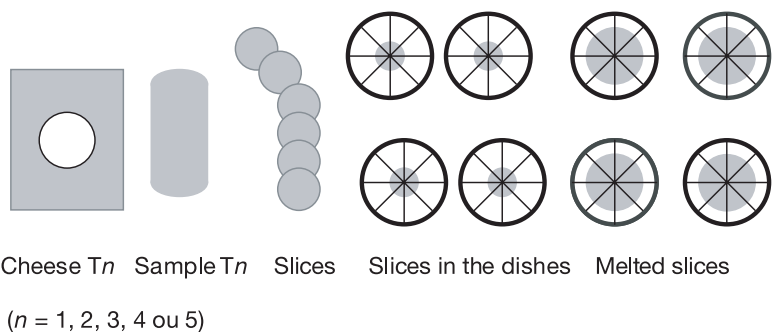

Figure 1. Schematic representation of the test to determine the melting capacity of the cheeses. using the equation: $\mathrm{FDM}=($ Fat $\times 1000) /$ TS. The moisture in defatted cheese (MDC) was calculated using the equation $\mathrm{MDC}=(\mathrm{M} \times 1000) /((\mathrm{TS}-$ Fat $)+\mathrm{M})$. The values for $\mathrm{pH}$ were determined by the potentiometric method and those for titratable acidity and the salt content using the AOAC method 920.124 [2] and the Volhard method [42], respectively. The salt content in the moisture $(\mathrm{S} / \mathrm{M})$ was calculated from the equation: $\mathrm{S} / \mathrm{M}=($ salt $\times 1000) /$ moisture. All the above determinations were carried out in triplicate on the cheeses after $10 \mathrm{~d}$ (D10) of refrigerated storage. In the same way, the $\mathrm{pH}$, TA and NCN of the cheeses were monitored after 25 and $45 \mathrm{~d}$ of refrigerated storage (D25 and D45).

Total fat and protein cheese recovery from the milk (FCR and PCR) was evaluated with the following equation:

FCR or PCR $=($ cheese mass $\times \%$ cheese component $\times 100) /($ milk or UFCM mass $\times \%$ milk or UFCM component),

where component means fat or protein.

\subsubsection{Evaluation of the melting capacity of the cheeses}

The melting capacity (MC) of Prato cheese was determined by the modified method of Schreiber, as described by Kosikowski [25]. The test was carried out in quadruplicate on the cheeses after 10, 25 and $45 \mathrm{~d}$ of storage (D10, D25 and D45).

For this test, one cheese from each treatment weighing about $0.5 \mathrm{~kg}$ was cut in half and a cylindrical sample removed from the center of one of the halves using a $0.036 \mathrm{~m}$ diameter bore. This cylinder was cut into $0.007 \mathrm{~m}$-thick slices using a modified egg slicer. Four slices of each sample (one from the surface, one from the center and 2 from the intermediary region) were placed individually in the center of a Petri dish marked with four lines at angles of $45^{\circ}$ (Fig. 1). The dishes were covered and left at room temperature for $30 \mathrm{~min}$. After this interval, the average initial diameter of each of the four slices was calculated as the average of the diameters in the four directions. Heating to evaluate melting was carried out for $7 \mathrm{~min}$ in an oven at $107^{\circ} \mathrm{C}$, after which the average final diameter was obtained in the same way as the average initial diameter. From these average diameters, the initial (Ai) and final (Af) areas of each slice were calculated and the melting capacity determined from these according to the equation: $\mathrm{MC}=(\mathrm{Af}-\mathrm{Ai}) \times 100 / \mathrm{Ai}$.

The arithmetic mean of the values for MC of the four slices of each sample provided the average melting capacity of each cheese.

\subsubsection{Experimental design and statistical analysis}

The statistical design adopted for this experiment was a split-plot block design, the treatments being applied to the plots and the time to the sub-plots. The batches of milk to be processed constituted the blocks. Three batches were carried out, one for each complete replicate, forming 3 blocks. The composition of the cheeses 
Table I. Average composition $(n=3)$ of the cheeses: standard (T1), ultrafiltered without prefermentation (T2), ultrafiltered with $10 \%$ of pre-fermentation (T3), ultrafiltered with $20 \%$ of prefermentation (T4), and ultrafiltered with $20 \%$ of pre-fermentation, and with indirect heating (T5).

\begin{tabular}{lcccccc}
\hline Variable & $\mathrm{T} 1$ & $\mathrm{~T} 2$ & $\mathrm{~T} 3$ & $\mathrm{~T} 4$ & $\mathrm{~T} 5$ & $\mathrm{LSD}^{1}$ \\
\hline $\mathrm{pH}$ & $5.37^{\mathrm{a}}$ & $5.37^{\mathrm{a}}$ & $5.28^{\mathrm{ab}}$ & $5.00^{\mathrm{b}}$ & $5.09^{\mathrm{ab}}$ & 0.23 \\
Titratable acidity & $0.64^{\mathrm{b}}$ & $0.71^{\mathrm{b}}$ & $0.86^{\mathrm{ab}}$ & $1.28^{\mathrm{a}}$ & $1.12^{\mathrm{ab}}$ & 0.35 \\
$(\%$ lactic acid) & & & & & \\
Total solids $\left(\mathrm{g} \cdot \mathrm{kg}^{-1}\right)$ & $517.70^{\mathrm{ab}}$ & $487.70^{\mathrm{b}}$ & $528.90^{\mathrm{ab}}$ & $549.50^{\mathrm{a}}$ & $554.70^{\mathrm{a}}$ & 38.62 \\
Moisture $\left(\mathrm{g} \cdot \mathrm{kg}^{-1}\right)$ & $482.30^{\mathrm{ab}}$ & $512.30^{\mathrm{a}}$ & $471.10^{\mathrm{ab}}$ & $450.50^{\mathrm{b}}$ & $445.30^{\mathrm{b}}$ & 38.62 \\
Fat $\left(\mathrm{g} \cdot \mathrm{kg}^{-1}\right)$ & $252.10^{\mathrm{a}}$ & $208.40^{\mathrm{a}}$ & $230.60^{\mathrm{a}}$ & $246.60^{\mathrm{a}}$ & $246.10^{\mathrm{a}}$ & 36.59 \\
FDM $\left(\mathrm{g} \cdot \mathrm{kg}^{-1}\right)$ & $487.80^{\mathrm{a}}$ & $425.80^{\mathrm{a}}$ & $433.80^{\mathrm{a}}$ & $449.20^{\mathrm{a}}$ & $443.00^{\mathrm{a}}$ & 55.53 \\
MDC $\left(\mathrm{g} \cdot \mathrm{kg}^{-1}\right)$ & $644.82^{\mathrm{ab}}$ & $647.00^{\mathrm{a}}$ & $610.68^{\mathrm{ab}}$ & $597.77^{\mathrm{ab}}$ & $590.41^{\mathrm{b}}$ & 37.15 \\
Fat recovery $(\%)$ & $87.31^{\mathrm{a}}$ & $64.39^{\mathrm{b}}$ & $67.08^{\mathrm{b}}$ & $72.37^{\mathrm{ab}}$ & $70.74^{\mathrm{ab}}$ & 11.98 \\
Total protein $\left(\mathrm{g} \cdot \mathrm{kg}^{-1}\right)$ & $184.20^{\mathrm{a}}$ & $213.80^{\mathrm{a}}$ & $225.10^{\mathrm{a}}$ & $218.60^{\mathrm{a}}$ & $222.40^{\mathrm{a}}$ & 30.99 \\
Protein recovery $(\%)$ & $70.58^{\mathrm{b}}$ & $80.17^{\mathrm{a}}$ & $80.54^{\mathrm{a}}$ & $80.68^{\mathrm{a}}$ & $82.46^{\mathrm{a}}$ & 4.46 \\
Salt $\left(\mathrm{g} \cdot \mathrm{kg}^{-1}\right)$ & $16.00^{\mathrm{a}}$ & $16.70^{\mathrm{a}}$ & $14.80^{\mathrm{a}}$ & $13.60^{\mathrm{a}}$ & $14.40^{\mathrm{a}}$ & 2.16 \\
Salt/Moisture $\left(\mathrm{g} \cdot \mathrm{kg}^{-1}\right)$ & $33.17^{\mathrm{a}}$ & $32.60^{\mathrm{a}}$ & $31.42^{\mathrm{a}}$ & $30.90^{\mathrm{a}}$ & $32.34^{\mathrm{a}}$ & 4.66 \\
\hline
\end{tabular}

* means with the same letter, in the same line, do not differ significantly from each other $(P>0.05)$ (Tuckey's multiple comparison method). ${ }^{1}$ least significant difference (LSD).

from the 5 treatments was evaluated statistically by the analysis of variance, using the procedure of multiple comparisons between pairs of means (Tukey's method) on the tenth day after manufacture of the cheeses. The data for the analyses of $\mathrm{pH}$, titratable acidity, non-casein nitrogen and melting capacity of the cheeses were evaluated in the same way as those for composition, on the tenth, twenty-fifth and forty-fifth days of storage. All the calculations were carried out with the aid of the SAS statistical program (SAS System for Windows, Release 8.02 - SAS Institute Inc., Cary, NC, USA).

\section{RESULTS AND DISCUSSION}

\subsection{Chemical composition}

\subsubsection{Average composition of the cheeses}

The cheeses made from non-ultrafiltered milk and from concentrated milk without pre-fermentation did not differ in terms of $\mathrm{pH}$ and TA (Tab. I). However, increasing the percentage of pre-fermented concentrate increased the TA of the cheeses and decreased the $\mathrm{pH}$ value, due to a greater incorporation of lactic acid from the pre-fermented UFCM and its considerable active starter incorporation, and as consequence, the $\mathrm{pH}$ and TA of cheeses T4 and T5 were different from those normally found in Prato cheese, which are: $\mathrm{pH}$ of 5.2 to $5.5[11,38]$ and about $0.86 \%$ lactic acid [44], respectively.

There was a significant difference for total solids between cheeses $\mathrm{T} 4$ and T5 with respect to $\mathrm{T} 2$, which presented the lowest total solids value, and although there was not a significant difference between treatments $\mathrm{T} 1, \mathrm{~T} 3, \mathrm{~T} 4$ and $\mathrm{T} 5$, from the practical point of view the treatments T3, T4 and T5 presented higher values than T1. The trend in the difference between treatments $\mathrm{T} 3, \mathrm{~T} 4$ and $\mathrm{T} 5$ with treatments $\mathrm{T} 1$ and $\mathrm{T} 2$ can also be observed in terms of moisture in deffated cheese 


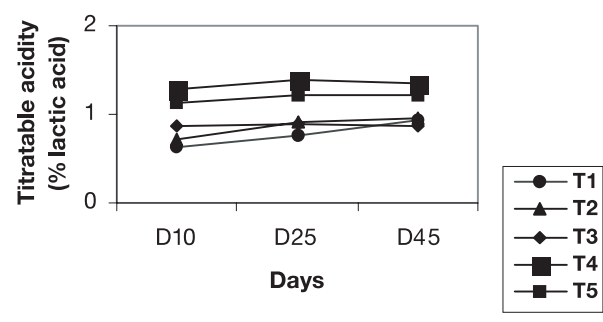

Figure 2. Evolution of TA during the $45 \mathrm{~d}$ of storage of the cheeses: standard (T1), ultrafiltered without pre-fermentation (T2), ultrafiltered with $10 \%$ of pre-fermentation (T3), ultrafiltered with $20 \%$ of pre-fermentation (T4), and ultrafiltered with $20 \%$ of pre-fermentation, and with indirect heating (T5).

(Tab. I) which shows that the treatments with retentate pre-fermentation presented similar lower values for MDC than treatments without it.

According to the Brazilian technical regulation for cheese identity and quality [6], Prato cheese is classified as a medium moisture content cheese (between 360 and $459 \mathrm{~g} \cdot \mathrm{kg}^{-1}$ ) and as a high fat cheese (FDM content between 450 and $599 \mathrm{~g} \cdot \mathrm{kg}^{-1}$ ), and thus only the cheeses from treatments $\mathrm{T} 4$ and T5 attained the legal norms with respect to moisture content, and only the standard cheese for FDM content (Tab. I). The cheeses made from ultrafiltered milk showed lower fat contents than those normally encountered in Prato cheese, which is from 260 to $290 \mathrm{~g} \cdot \mathrm{kg}^{-1}$ [11], and consequently did not present adequate FDM values.

The data presented in Table I show that, although statistically there was no significant difference between the fat contents or between the protein contents of the cheeses from the different treatments, in practical terms there were differences. Treatment T2 presented the lowest fat and fat in dry matter content and the use of pre-fermentation presented a tendency to increase the fat content of the ultrafiltered cheeses, such that T4 and T5 cheeses presented FDM values near to the minimum required by

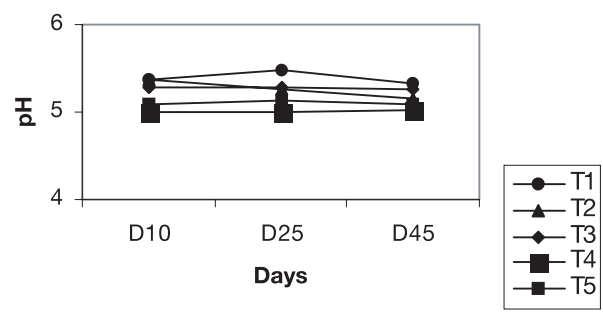

Figure 3. Evolution of $\mathrm{pH}$ during the $45 \mathrm{~d}$ of storage of the cheeses: standard (T1), ultrafiltered without pre-fermentation (T2), ultrafiltered with $10 \%$ of pre-fermentation (T3), ultrafiltered with $20 \%$ of pre-fermentation (T4), and ultrafiltered with $20 \%$ of pre-fermentation, and with indirect heating (T5).

the current legislation. The UFCM cheeses presented lower values for fat recovery in cheeses, with a significant difference between the treatments $\mathrm{T} 2$ and $\mathrm{T} 3$ with respect to $\mathrm{T} 1$, with $\mathrm{T} 2$ presenting the lowest value. Fat losses in processing were the main factor affecting the cheeses' composition. Such losses have already been reported in the literature [29] and have been attributed to a coarser UFCM cheese structure. Data from these authors being prepared for publication have shown differences in microstructure between UFCM cheeses with and without pre-fermentation, which helps to explain such differences in fat losses.

There was a significant difference for cheese protein recovery between cheeses $\mathrm{T} 2, \mathrm{~T} 3, \mathrm{~T} 4$ and $\mathrm{T} 5$ with respect to T1, which presented the lowest value, and as consequence $\mathrm{T} 1$ presented the smallest total protein content.

\subsubsection{Evolution of $\mathrm{pH}$ and titratable acidity of the cheeses}

Figures 2 and 3 show, respectively, the evolution of TA and of the $\mathrm{pH}$ of the cheeses from the five treatments during the $45 \mathrm{~d}$ of refrigerated storage.

A statistical analysis of the data for TA provided the following information: there 
was no interaction for treatment $\times$ time $(P=0.24)$ and the values for TA of the cheeses showed statistically significant variations with time $(P<0.01)$ and with the type of treatment adopted $(P=0.02)$. The TA of the treatments increased significantly between the dates D10 and D25, although there were no significant differences between days D25 and D45. With respect to the treatments, according to Tukey's test, T1 did not differ significantly from treatments T2, T3 and T5, although it did differ from T4. T4 also differed from $\mathrm{T} 1$, but not from the other treatments.

An analysis of the data for $\mathrm{pH}$ showed there was no interaction of treatment $x$ time $(P=0.75)$ and the factor time did not significantly influence $(P=0.45)$ the $\mathrm{pH}$ values of the different cheeses. However, these values were significantly influenced $(P=0.03)$ by the type of treatment adopted for the cheeses. Based on Tukey's test, it was shown that the $\mathrm{pH}$ data for $\mathrm{T} 1$ did not differ statistically from those obtained for treatments T2, T3 and T5 but did differ from those of $\mathrm{T} 4$. The values for $\mathrm{T} 4$ also differed from those observed for $\mathrm{T} 1$, but not from those observed for the other treatments.

The use of both UFCM and UFCM with $100 \mathrm{~g} \cdot \mathrm{kg}^{-1}$ pre-fermentation of the retentate did not significantly alter the acidity or $\mathrm{pH}$ of the cheeses. However, $200 \mathrm{~g} \cdot \mathrm{kg}^{-1}$ pre-fermentation of the UFCM increased the TA of the cheeses (Fig. 2) and decreased the $\mathrm{pH}$ value (Fig. 3). The type of heating adopted did not interfere in the TA and $\mathrm{pH}$ of these cheeses (Figs. 2 and 3), this result disagreeing with information found in the literature [45, 47] which attributed the lower acidity of cheeses elaborated with direct heating to a leaching effect of the curd by the hot water.

The TA of the five treatments increased between the tenth and twenty-fifth days of storage (Fig. 2), probably, according to Fox et al. [10], due to fermentation of the residual lactose by the starter. Although the TA of the cheeses increased during this

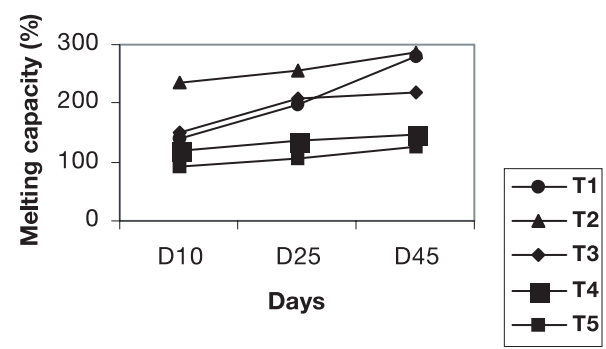

Figure 4. Evolution of melting capacity during the $45 \mathrm{~d}$ of storage of the cheeses: standard (T1), ultrafiltered without pre-fermentation (T2), ultrafiltered with $10 \%$ of pre-fermentation (T3), ultrafiltered with $20 \%$ of pre-fermentation (T4), and ultrafiltered with $20 \%$ of pre-fermentation, and with indirect heating (T5).

period, the $\mathrm{pH}$ values did not decrease, due to the buffering capacity presented by the cheeses after $10 \mathrm{~d}$ of storage. According to Fox et al. [10], the buffering capacity of cheeses greatly increases when the $\mathrm{pH}$ presents values below 5.5, and all the cheeses manufactured in this experiment presented $\mathrm{pH}$ values below 5.5 on D10 (Fig. 3).

The cheeses made from partially prefermented (100 and $200 \mathrm{~g} \cdot \mathrm{kg}^{-1}$ ) UFCMs, showed similar behavior for $\mathrm{pH}$ to that found by Metzger et al. [35]. These researchers studied the behavior of Mozzarella cheese made from milk chemically preacidified to different $\mathrm{pH}$ values, during $90 \mathrm{~d}$ of storage, and showed that the $\mathrm{pH}$ values either remained stable or decreased with time.

\subsubsection{Evolution of the melting capacity of the cheeses}

The melting capacity of the cheeses can be visualized in Figure 4.

The statistical analysis of the MC data provided the following information: there was no interaction between treatment $x$ time $(P=0.49)$, and the type of treatment did not significantly influence $(P=0.25)$ 
Table II. Average non-casein nitrogen $(n=3)$ of the cheeses: standard (T1), ultrafiltered without pre-fermentation (T2), ultrafiltered with $10 \%$ of pre-fermentation (T3), ultrafiltered with $20 \%$ of pre-fermentation (T4), and ultrafiltered with $20 \%$ of pre-fermentation, and with indirect heating (T5).

\begin{tabular}{lccccc}
\hline \multirow{2}{*}{ Storage } & \multicolumn{5}{c}{ Non-casein nitrogen $\left(\mathrm{g} \cdot \mathrm{kg}^{-1}\right)$} \\
\cline { 2 - 6 } D10 & $\mathrm{T} 1$ & $\mathrm{~T} 2$ & $\mathrm{~T} 3$ & $\mathrm{~T} 4$ & $\mathrm{~T} 5$ \\
\cline { 2 - 6 } & 2.80 & 4.30 & 4.70 & 6.20 & 5.50 \\
D25 & 4.00 & 5.70 & 6.30 & 7.40 & 6.90 \\
D45 & 4.80 & 6.60 & 7.60 & 9.50 & 8.50 \\
\hline
\end{tabular}

this functional property, although the latter did suffer significant alterations $(P<0.01)$ with time. According to Tukey's test, $\mathrm{MC}_{\mathrm{D} 10}<\mathrm{MC}_{\mathrm{D} 25}=\mathrm{MC}_{\mathrm{D} 45}$.

The MC of the cheeses from the five treatments increased during storage, probably due to cheese proteolysis and degradation of the protein matrix, which probably resulted in the loss of the cheese's ability to maintain its structure during heating $[4,20$, $33,43,46]$. The loss of matrix integrity is reported as one of the main factors determining the increase in $\mathrm{MC}$ of cheeses [28, 33]. The cheeses manufactured in this experiment suffered primary proteolysis (PP) during storage (Tab. II) (PP-D10 < PP-D25 < PP-D45), which in part justifies the increase in $\mathrm{MC}$ observed during refrigerated storage.

Although the increase in $\mathrm{MC}$ of cheeses observed during storage is normally associated with cheese proteolysis, it has also been reported that changes in water partitioning from expressible water to entrapped water can be responsible for changes in the cheeses' melting capacity [14, 28, 33].

During storage, a decrease in expressible water of the cheese usually occurs (water whose mobility is not impeded by the macro-structure of the protein matrix and which can be expressed by centrifugation), such water being found together with the fat and the starter organisms in vacuoles and elongated pockets [33, 39]. According to McMahon et al. [33], after salting of the cheese, reorganization of the protein matrix possibly occurs, with subsequent absorption of water by these vacuoles/pockets during refrigerated storage. Thus the expressible water decreases since it becomes entrapped water (water physically retained in the spaces between the sub-aggregates of protein that form the basic structure of the protein matrix), and as this phenomenon progresses, so the protein network becomes more hydrated and some interactions between proteins are substituted by interactions between protein and entrapped water, factors which allow the cheese to melt more easily [33].

According to Guo and Kindstedt [14] and McMahon et al. [33], one can obtain expressible water from cheeses for a maximum of $20 \mathrm{~d}$. In this experiment, the cheeses presented an increase in MC during storage (Fig. 4), although this increase was only significant between the tenth and twenty-fifth days of storage, the increase in MC occurring during this period being a function of proteolysis occurring in the cheeses and of changes in the proteinprotein and protein-moisture interactions. After this period the MC continued to increase, although not significantly, since it only suffered an additional effect of proteolysis, which continued to occur.

Since the property of melting is influenced by numerous physical and chemical factors, even cheeses belonging to the same category may respond differently to the same time $\times$ temperature binomial of heating [21]. Thus it becomes difficult to compare the results in Figure 4 with those obtained by other authors using different processing conditions. It was only possible to verify that in this experiment, as in those carried out by other authors $[35,37,43,48$, 49], the MC of the cheeses increased during storage, mainly during the first $25 \mathrm{~d}$.

Metzger et al. [35], working with Mozzarella cheese from milk chemically pre-acidified to different $\mathrm{pH}$ values and comparing them with Mozzarella made with normal milk, also showed that the MC of the cheeses was 
not affected by pre-acidification $(P>0.05)$, but was affected by time $(P<0.05)$.

Although no significant differences in MC were observed between the treatments in this experiment, in data of Figure 4 a tendency for the following behavior can be observed: MCT4 = MCT5 < MCT1 = MCT3 < MCT2, mainly in the period between D10 and D25.

Treatments T1, T2 and T3 presented a greater tendency to melt due to their greater ratio of water to protein $(2.62,2.4$ and 2.10 , respectively), resulting probably in a more hydrated protein matrix, which, according to McMahon et al. [33], allows the proteins to flow more easily when heated, increasing the melting capacity of the cheese. However, considering that these cheeses were exposed to the same time $\times$ temperature heating binomial, the less moist cheeses with greater fat contents (T1 and T3) tended to transfer heat more rapidly to the protein matrix, which thus received a greater amount of energy [9].

Lefevere et al. [28] observed that, during the heating of cheese, part of the heat is used to rearrange the protein-protein interactions. Thus when the cheese is heated, the protein matrix absorbs part of the energy, which influences the interactions that maintain the protein structure, and in the range from 60 to $80^{\circ} \mathrm{C}$, protein unfolding starts to occur, exposing hydrophobic sites and leading to a greater aggregation between the protein molecules [27] and, according to Lefevere et al. [28], greater protein-protein interaction results in lower MC. Thus the T2 cheese may have presented a higher MC as a function of less protein-protein aggregation.

Treatments $\mathrm{T} 4$ and $\mathrm{T} 5$, in addition to having smaller ratios of water to protein in the cheese, also presented lower $\mathrm{pH}$ values, justifying their lower MC values (Fig. 4). Ramkumar et al. [39] observed that the amount of whey centrifuged from a model Cheddar cheese decreased with increase in $\mathrm{pH}$ of the curd, suggesting that the capacity of the curd to physically retain water mol- ecules, like the casein-moisture interactions in the cheese, were $\mathrm{pH}$-sensitive. Kindstedt et al. [23], working with Mozzarella cheese, also reported that the $\mathrm{pH}$ strongly affected the protein-moisture interactions and consequently the melting of the cheese, the cheeses losing their melting capacity at $\mathrm{pH}$ values below 5.0.

\section{CONCLUSIONS}

It is possible to manufacture Prato-type cheese from milk concentrated by ultrafiltration $(\mathrm{CF}=4: 1)$ with a proximate composition similar to that of cheese produced from non-concentrated milk.

The pre-fermentation of $200 \mathrm{~g} \cdot \mathrm{kg}^{-1}$ of the retentate increases the acidity and decreases the $\mathrm{pH}$ of the cheeses. The type of cooking does not interfere with these parameters.

The time factor does not influence the $\mathrm{pH}$ values but does increase the titratable acidity and melting capacity of the cheeses.

There was statistically no difference in melting capacity between the cheeses from the different treatments, although there was a tendency for the cheeses with a greater amount of entrapped water, due to a greater water, to protein ratio and higher $\mathrm{pH}$ values, to melt more.

\section{ACKNOWLEDGEMENTS}

The authors are grateful to $\mathrm{CNPq}$ (doctorate scholarships) and to FAPESP (Research financing 00/14079-8).

\section{REFERENCES}

[1] Andersen A.B., Fabricação do queijo Prato e Gouda, Rev. Ceres 3 (1941) 187-189.

[2] Association of Analytical Chemists-AOAC, Official methods of analysis of AOAC international, AOAC, Washington, USA, 1995. 
[3] Barbano D.M, Lynch J.M., Fleming J.R., Direct and indirect determination of true protein content of milk by Kjeldahl analysis: collaborative study, J. Assoc. Off. Anal. Chem. 74 (1991) 281-284.

[4] Barbano D.M., Hong Y., Yun J.J., Larose K.L., Kindstedt P.S., Mozzarella cheese: impact of three commercial culture strains on composition, yield, proteolysis, and functional properties, Proceedings of 31st Annual Marschall Invitational Italian Cheese Seminar, Madison, Wisconsin, USA, 1995.

[5] Bogenrief D.D., Olson N.F., Hydrolysis of $\beta$-casein increases Cheddar cheese meltability, Milchwissenschaft 50 (1995) 678-682.

[6] Brasil, Nova legislação de produtos lácteos e de alimentos para fins especiais, diet, light e enriquecidos, Fonte Comunicações e Editora, São Paulo, Brasil, 1998.

[7] British Standards Institution, Determination of fat content of milk and milk products Gerber method - Methods, British Standards Institution, London, UK, 1989.

[8] El-Gazzar F.E., Marth E.H., Ultrafiltration and reverse osmosis in dairy technology: a review, J. Food Prot. 54 (1991) 801-809.

[9] Fife R.L., McMahon D.J., Oberg C.J., Functionality of low fat Mozzarella cheese, J. Dairy Sci. 79 (1996) 1903-1910.

[10] Fox P.F., Lucey J.A., Cogan T.M., Glycolysis and related reactions during cheese manufacture and ripening, Food Sci. Nutr. 29 (1990) 237-253.

[11] Furtado M.M., Lourenço Neto J.P.M., Tecnologia de queijos: manual técnico para a produção industrial de queijos, Dipemar Ltda, São Paulo, Brasil, 1994.

[12] Goudédranche H., Maubois J.L., Ducruet P., Mahaut M., Utilisation de nouvelles membranes minérales d'ultrafiltration pour la fabrication de fromages du type Saint-Paulin, Tech. Lait. 950 (1981) 7-13.

[13] Green M.L., Glover F.A., Scurlock E.M.W., Marshall R.J., Hatfield D.S., Effect of use of milk concentrated by ultrafiltration on the manufacture and ripening of Cheddar cheese, J. Dairy Res. 48 (1981) 333-341.

[14] Guo M.R., Kindstedt P.S., Age-related changes in the water phase of Mozzarella cheese, J. Dairy Sci. 78 (1995) 2099-2107.

[15] Hickey M.W., Ultrafiltration specialty cheese workshop, Aust. J. Dairy Technol. 48 (1993) 40-48.

[16] Jameson G.W., Manufacture of Cheddar cheese from milk concentrated by ultrafiltration: the development and evaluation of a process, Food Technol. Aust. 39 (1987) 560-564.
[17] Jensen G.K., Stapelfeldt H., Incorporation of whey proteins in cheese including the use of ultrafiltration, in: Factors affecting the yield of cheese, Special Issue 9301, Int. Dairy Fed., Brussels, Belgium, 1993, pp. 88-105.

[18] Jensen L.A., Johnson M.E., Olson N.F., Composition and properties of cheeses from milk concentrated by ultrafiltration and reverse osmosis - a review of literature, Cult. Dairy Prod. J. 22 (1987) 6-10.

[19] Kindstedt P.S., Functional properties of Mozzarella cheese on pizza: a review, Cult. Dairy Prod. J. 26 (1991) 27-31.

[20] Kindstedt P.S., Effect of manufacturing factors, composition, and proteolysis on the functional characteristics of Mozzarella cheese, Crit. Rev. Food Sci. Nutr. 33 (1993) 167-187.

[21] Kindstedt P.S., Mozzarella and pizza cheese, in: Fox P.F. (Ed.), Cheese: chemistry, physics and microbiology, Chapman \& Hall, London, UK, 1993, pp 337-362.

[22] Kindstedt P.S., Yun J.J., Barbano D.M. Larose K.L., Mozzarella cheese: impact of coagulant concentration on chemical composition, proteolysis, and functional properties, J. Dairy Sci. 78 (1995) 2591-2597.

[23] Kindstedt P.S., Zielinski A., Almena-Aliste M., Ge C., A post-manufacture method to evaluate the effect of $\mathrm{pH}$ on Mozzarella cheese characteristics, Aust. J. Dairy Technol. 56 (2001) 14-19.

[24] Kosikowski F., The manufacture of Mozzarella and related cheese by ultrafiltration, Cult. Dairy Prod. J. 10 (1976) 15-16.

[25] Kosikowski F., Cheese and fermented milk foods, Edwards Brothers, Ann Arbor, Michigan, 1982.

[26] Kosikowski F., New cheese making procedures utilizing ultrafiltration, Food Technol. 40 (1986) 71-77.

[27] Kuo M.I., Wang Y.C., Gunasekaran S., Olson N.F., Effect of heat treatments on the meltability of cheeses, J. Dairy Sci. 84 (2001) 1937-1943.

[28] Lefevere I., Dewettinck K., Huyghebaert A., Cheese fat as driving force in cheese flow upon melting, Milchwissenschaft 55 (2000) 563-566.

[29] Lelievre J., Lawrence R.C., Manufacture of cheese from milk concentrated by ultrafiltration, J. Dairy Res. 55 (1988) 465-478.

[30] Lucey J., Kelly J., Cheese yield, J. Soc. Dairy Technol. 47 (1994) 1-14.

[31] Maubois J.L, Mocquot G., Application of membrane ultrafiltration to preparation of various types of cheese, J. Dairy Sci. 58 (1975) 1001-1007. 
[32] Maubois J.L., Mocquot G., Vassal L., Procédé de traitement du lait et de sous-produits laitiers, French Patent, FR 2.052.121, 1969.

[33] McMahon D.J., Fife R.L., Oberg C.J., Water partitioning in Mozzarella cheese and its relationship to cheese meltability, J. Dairy Sci. 82 (1999) 1361-1369.

[34] Mello F., Furtado M.M., Queijo Pratoobtendo melhor qualidade e maior rendimento, Ind. Laticínios 6 (2001) 28-32.

[35] Metzger L.E., Barbano D.M., Kindstedt P.S., Guo M.R., J. Dairy Sci. 84 (2001) 1348-1356.

[36] Morris C.E., Is this the cheese plant of the future?, Food Eng. 56 (1984) 99-100.

[37] Oberg C.J, Wang A., Moyes L.V., Brown R.J., Richardson G.H., Effects of proteolytic activity of thermolactic cultures on physical properties of Mozzarella cheese, J. Dairy Sci. 74 (1991) 389-397.

[38] Oliveira J.S., Queijo: fundamentos tecnológicos, Ícone Editora Ltda, São Paulo, Brasil, 1986.

[39] Ramkumar C., Creamer L.K., Johnston K.A., Bennett R.J., Effect of $\mathrm{pH}$ and time on the quantity of readly available water within fresh cheese curd, J. Dairy Res. 64 (1997) 123-134.

[40] Renner E., Abd El-Salam M.H., Application of ultrafiltration in the dairy industry, Elsevier Applied Science, London, UK, 1991.

[41] Ribeiro E.P., Aplicação da ultrafiltração de leite no processo de fabricação de queijo tipo prato, tese, Faculdade de Engenharia de Alimentos, Universidade Estadual de Campinas, Brasil, 1996.
[42] Richardson G.H., Standard Methods for Examination of Dairy Products, American Publ. Health Assoc, Washington, USA, 1985.

[43] Rudan M.A., Barbano D.M., Yun J.J., Kindstedt P.S., Effect of fat reduction on chemical composition, proteolysis, functionality and yield of Mozzarella cheese, J. Dairy Sci. 82 (1999) 661-672.

[44] Schiftan T.Z., Komatsu I., Estudos sobre a composição de queijo prato consumido na cidade de São Paulo, Rev. Inst. Laticínios Cândido Tostes 35 (1980) 33-38.

[45] Souza E.A., Tecnologia da fabricação de queijos, Editora Lar Católico, Juiz de Fora, Brasil, 1960.

[46] Tunick M.H, Mackey K.L., Shieh J.J., Smith P.W., Cooke P., Malin E.L., Rheology and microstructure of low-fat Mozzarella cheese, Int. Dairy J. 3 (1993) 649-662.

[47] Van Dender A.G.F., Ducruet P., Maubois J.L., Estudo da fabricação de queijo tipo Prato utilizando ultrafiltração, Rev. Inst. Laticínios Cândido Tostes 42 (1987) 7-14.

[48] Yun J.J, Barbano D.M., Kiely L.J, Kindstedt P.S., Mozzarella cheese: impact of cooking temperature on chemical composition, proteolysis and functional properties, J. Dairy Sci. 76 (1993) 3664-3673.

[49] Yun J.J., Barbano D.M., Larase K.L., Kindstedt P.S., Impact of whey $\mathrm{pH}$ at draining on chemical composition, proteolysis and functional properties, J. Dairy Sci. 78 (1995) 1-7.

[50] Zoon P., Incorporation of whey proteins into Dutch-type cheese, in: Cheese yield and factors affecting its control, Special Issue 9402, Int. Dairy Fed., Brussels, Belgium, 1994, pp. 403-408. 